\title{
MIR125B2 Pre-miRNA
}

National Cancer Institute

\section{Source}

National Cancer Institute. MIR125B2 Pre-miRNA. NCI Thesaurus. Code C82758.

MIR125B2 is an oligoribonucleotide that is encoded by the human MIR125B2 gene and is involved in the regulation of gene expression. 